Publisher: ROYAL SOC CHEMISTRY, THOMAS GRAHAM HOUSE, SCIENCE PARK, MILTON RD,, CAMBRIDGE CB4 OWF, CAMBS, ENGLAND

Subject Category: Chemistry, Analytical

IDS Number: 530VY

ISSN: 0003-2654

DOI: $10.1039 / b 110686 b$

http://www.rsc.org/publishing/journals/AN/article.asp?doi=b110686b

\title{
FLOW INJECTION DETERMINATION OF READILY ASSIMILABLE NITROGEN COMPOUNDS DURING VINIFICATION
}

\section{J. González-Rodríguez, ${ }^{\text {a }}$ P. Pérez-Juan ${ }^{\mathrm{a}}$ and M.D. Luque de Castro ${ }^{* b}$}

${ }^{a}$ R\&D Department, Pérez Barquero S.A., Avda. de Andalucía 27, E-14550 Montilla, Córdoba, Spain. E-mail: barquero@fiab.es

b Analytical Chemistry Division, University of Córdoba, Campus of Rabanales, Annex C-3, E-14071, Córdoba, Spain. E-mail: qa1lucam@uco.es; Fax:+34 957 218615

A flow injection method for the determination of readily assimilable nitrogen (r.a.n.), i.e. ammonium and aminated nitrogen, is reported. The difference in $\mathrm{pH}$ of the sample in the presence and absence of formaldehyde, which blocks the amino function, provides the value of r.a.n. by monitoring the changes in absorbance of bromothymol blue at $616 \mathrm{~nm}$. The detection and quantification limits are 10 and $11.6 \mathrm{mg} \mathrm{l}^{-1}$, respectively; the reproducibility and repeatability are $3.94 \mathrm{mg} \mathrm{l}^{-1}$ and $1.35 \mathrm{mg} \mathrm{l}^{-1}$, respectively; and the sample throughput is 20 samples $\mathrm{h}^{-1}$. The method has been applied to the analysis of 120 samples of must and wine subjected to biological aging. The proposed method also provides good correlation with the reference method used in routine analysis, and it is faster and gives sufficient precision for wineries requirements.

Keywords: wine, must, flow injection, spectrophotometry, nitrogen, ammonium, amines 


\section{Introduction}

The availability of nitrogen compounds to yeast is of paramount importance for a good development of wine fermentation. Total nitrogen in either must or wine includes inorganic and organic forms, and is measured after the mineralisation of all forms of nitrogen in the sample by the addition of sulfuric acid and heating. Nitrogen forms are thus converted into ammonium sulfate, which is removed by distillation after the addition of sodium hydroxide, and then assayed by titration with an acid solution (Kjeldahl method). The total nitrogen concentration in wines varies from 70 to $400 \mathrm{mg} \mathrm{l}^{-1}$ for white wines and from 140 to $700 \mathrm{mg} \mathrm{l}^{-1}$ for red wines. ${ }^{1}$

Nitrogenated substances may therefore represent up to $20 \%$ of the dry extract in dry wines. The influence of ammonium and aminated nitrogen on both, the start and rate of the fermentation process, has been demonstrated. $^{2}$ Completeness of sugar transformation also depends on the concentration of these compounds, together with the functioning of the yeast. The amount of ammonium varies from 30 to $100 \mathrm{mg} \mathrm{l}^{-1}$ in must and up to $10 \mathrm{mg} \mathrm{l}^{-1}$ in red and white wines; ${ }^{2}$ meanwhile, the amount of aminated nitrogen varies from 80 to $300 \mathrm{mg} \mathrm{l}^{-1}$ in must, from 60 to $200 \mathrm{mg} \mathrm{l}^{-1}$ in red wines and from 10 to $150 \mathrm{mg} \mathrm{l}^{-1}$ in white wines. ${ }^{2}$

The analysis of each fraction must be made separately. Thus, the analysis of aminated nitrogen makes use of the reaction with 2, 4, 6-trinitrobenzenesulfonic acid $\left(\right.$ TNBS) ${ }^{3}$ or ninhydrine, ${ }^{4}$ and that of ammonium is based on retention on an ionic exchange resin and subsequent tritation with hydrochloric acid. ${ }^{5}$ However, a simpler technique for the determination of both parameters involves an official Italian legislative method. ${ }^{6}$ It consists of blocking the aminic function using formaldehyde, followed by potentiometric titration with sodium hydroxide using a pH electrode. This is a not a precise method, but its precision is sufficient for an estimated value of readily assimilable nitrogen (r.a.n.) by yeast during fermentation, Thus, it is commonly used in winery laboratories.

No automated methods for the joint determination of ammonium and amino nitrogen have been described in the literature. The only method is to determine both parameters individually. Several automated methods have been reported for the analysis of amines, but none gives the overall amine content. Primary, ${ }^{7}$ secondary ${ }^{8}$ and tertiary $^{9}$ amines are usually determined fluorimetrically after derivatisation.

Flow injection (FI) methods for the determination of ammonium in a great variety of matrices have been widely described in the literature.

Nevertheless, there is scarce information on the determination of this analyte in wines and must. Only one method for the determination of ammonium in wine, using gas diffusion and bulk acoustic wave detection, has been described. ${ }^{10}$ 


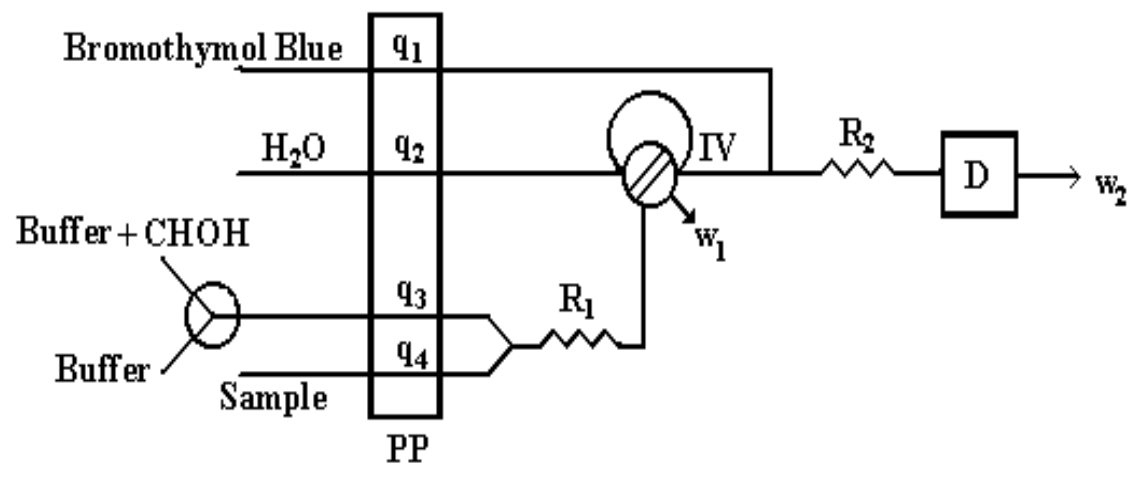

Figure 1. Manifold for the determination of readily assimilable nitrogen. $P P=$ peristaltic pump, $\mathrm{SV}=$ selection valve, $\mathrm{IV}=$ injection valve, $\mathrm{R}=$ reactor, $\mathrm{D}=$ detector, $\mathrm{w}=$ waste, $\mathrm{q}=$ flow-rate.

The objective of this work was to develop a rapid method for the determination of r.a.n. with sufficient precision for winery requirements: (i) to guarantee the monitoring of the fermentation process; and (ii) for use to monitor this parameter during the biological aging of Sherry-type wines.

\section{Experimental}

\section{Apparatus and instruments}

The manifold used is outlined in Fig.1. It was built using a four-channel Gilson Minipuls-3 peristaltic pump (Villiers le Bel, France) fitted with a rate selector; two Rheodyne 5041 injection valves (Elkay, Galway, Ireland), one of them used as selection valve, and PTFE tubing of $0.5 \mathrm{~mm}$ i.d. (Scharlau, Barcelona, Spain). A PU 8625 spectro- photometer (Cambridge, UK) equipped with a Hellma 138-QS flow-cell (Hellma, Jamaica, NY) and connected to a Knauer recorder, was also used.

Statistical treatments were made using statgraphics ${ }^{\mathrm{TM}}$ plus for windows 2.1.

\section{Reagents and solutions}

For the reference method, 0.1 and $1 \mathrm{M}$ sodium hydroxide solutions, $0.5 \mathrm{M}$ of barium chloride solution, hydrochloric acid and $40 \%$ (v/v) formaldehyde solution, all from Panreac (Barcelona, Spain) were used.

For the proposed method, $6 \times 10^{-4} \mathrm{M}$ bromothymol blue in $14 \mathrm{~g} \mathrm{l}^{-1}$ phosphate-buffered solution at $\mathrm{pH} 8$, both from Merck (Darmstadt, Germany) and $6 \%$ (v/v) formaldehyde in $5 \mathrm{~g} \mathrm{l}^{-1}$ phosphate buffered solution at 
pH 11.5, from Panreac and Merck, were used.

All solutions were prepared using doubly distilled water of high purity obtained from a Millipore Milli-Q plus system (Bedford, MA, USA).

\section{Reference procedure}

One hundred millilitres of either must or wine was taken and its $\mathrm{pH}$ was adjusted to 8 with $1 \mathrm{M} \mathrm{NaOH}$. Then, 10 $\mathrm{ml}$ of $0.5 \mathrm{M}$ barium chloride was added. After $15 \mathrm{~min}$, the suspension was diluted to $200 \mathrm{ml}$ and filtered. One hundred millilitres of the filtered solution was taken and again the $\mathrm{pH}$ was adjusted to 8 if necessary. Twenty five millilitres of formaldehyde solution was added, and $15 \mathrm{~min}$ later, the mixture was titrated to $\mathrm{pH} 8$ with $0.1 \mathrm{M}$ sodium hydroxide. The content of r.a.n. in wine was obtained by multiplying by 28 the millilitres of $\mathrm{NaOH}$ used. The result is expressed in $\mathrm{mg} \mathrm{l}^{-1}$.

\section{Proposed method}

Figure 1 shows the manifold used for the proposed determination. The sample was driven to merge with buffer solution with or without formaldehyde and both were homogenised along $\mathrm{R}_{1}$ and introduced into the loop of the injection valve (IV). The sequence was as follows: with the selection valve (SV) in the position for supplying buffer solution alone, valve IV was switched to the injection position, the injected plug merged with a stream of bromothymol blue and the absorbance at $616 \mathrm{~nm}$ was monitored. After this, SV was switched to the position for aspirating buffer + formaldehyde solution, and the new sample thus diluted filled the loop of IV and was then injected. The difference in absorbance between the two measurements at 616 $\mathrm{nm}$ gave the value of r.a.n.

The analytical signal varies due to the difference in the sample $\mathrm{pH}$ in the presence and absence of formaldehyde. This compound blocks the amino function and the subsequent change in $\mathrm{pH}$ is monitored through its effect on the absorbance of bromothymol blue measured at $616 \mathrm{~nm}$.

\section{Results and discussion}

\section{Optimisation of the method}

The variables which affect the method for the determination of the target parameter were studied by either the multivariate or univariate approach depending on the existence or not of interrelated variables. The ranges studied and the optimal values found are shown in Table 1.

\section{Chemical variables}

Figure 2 shows a plot of the absorbance values versus both indicator buffer and formaldehyde in the solution that merges with the sample. Because the $P$ value in the ANOVA table is less than 0.01 , there is a statistically significant relationship between the variables at 99\% confidence level. The equation of the fitted model is: Abs $=0.419-6 \times 10^{-4}$ [buffer] $+4.5 \times 10^{-4}$ [formaldehyde]. There are not significant differences in the absorbance produced by the lowest and highest concentrations of the buffer 
(the absorbance changes between 0.408 and 0.436). A similar behaviour is observed for the instrumental variable versus formaldehyde concentration. Thus, the lowest concentrations were selected for further experiments in order to save reagents. Both the range studied and the optimum value found for other variables are summarised in Table 1.

Table 1. Optimisation of variables

\begin{tabular}{lll}
\hline Variable & Tested range & Optimum value \\
\hline Chemical & & \\
\hline Formaldehyde (\%) (v/v) & $1-40$ & 6 \\
Formaldehyde buffer/ $\mathrm{g} \mathrm{l}^{-1}$ & $2-16$ & 14 \\
Indicator buffer/ $\mathrm{g} \mathrm{l}^{-1}$ & $2-16$ & 5 \\
Bromothymol blue/ M & $10^{-5}-10^{-4}$ & $6 \times 10^{-4}$ \\
Flow Injection & & \\
$\mathrm{q}_{1}=\mathrm{q}_{3}=\mathrm{q}_{4} / \mathrm{ml} \mathrm{min}^{-1}$ & $0.32-1.2$ & 0.7 \\
$\mathrm{q}_{2} / \mathrm{ml} \mathrm{min}^{-1}$ & & 0.4 \\
Sample volume/ $\mu \mathrm{l}$ & $50-500$ & 100 \\
$\mathrm{R}_{1}=\mathrm{R}_{2} / \mathrm{cm}$ & $50-180$ & 75 \\
\hline
\end{tabular}

\section{Flow injection variables}

The functions of reactors $R_{1}$ and $R_{2}$ were to provide appropriate reagentsample mixtures before reaching the IV and the detector, respectively. Lengths of $75 \mathrm{~cm}$ were sufficient for these purposes. Fig. 3 shows a plot of the absorbance versus the flow rate

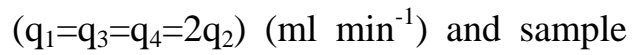
volume $(\mu \mathrm{l})$, where the saddle-like response surface of the optimisation study was adjusted to the equation: Abs $=2.5-3.6 q+0.004 V+1.2 q^{2}+$ $0.004 \mathrm{qV}-9 \times 10^{-7} \mathrm{~V}^{2}$, where $\mathrm{q}$ is the flow-rate and $\mathrm{V}$ is the sample volume. Optimal values of $0.7 \mathrm{ml} \mathrm{min}^{-1}$ and 100 $\mu \mathrm{l}$ were found for $\mathrm{q}$ and $\mathrm{V}$, respectively. A low carrier flow-rate $\left(0.4 \mathrm{ml} \mathrm{m^{-1 } )}\right.$ was selected in order to minimise dispersion.

\section{Characterisation of the method}

\section{Calibration curves}

Calibration curves were run using as standard solutions wine and must samples spiked with known concentrations of ammonium (between 10 and $75 \mathrm{mg} \mathrm{l}^{-1}$ and between 10 and $400 \mathrm{mg} \mathrm{l}^{-}$ ${ }^{1}$ for wines and must, respectively) in order to minimise matrix effects due to organic acids present in wine and must. The content of assimilable nitrogen in wines and must prior to spiking was determined in triplicate by the reference method. 


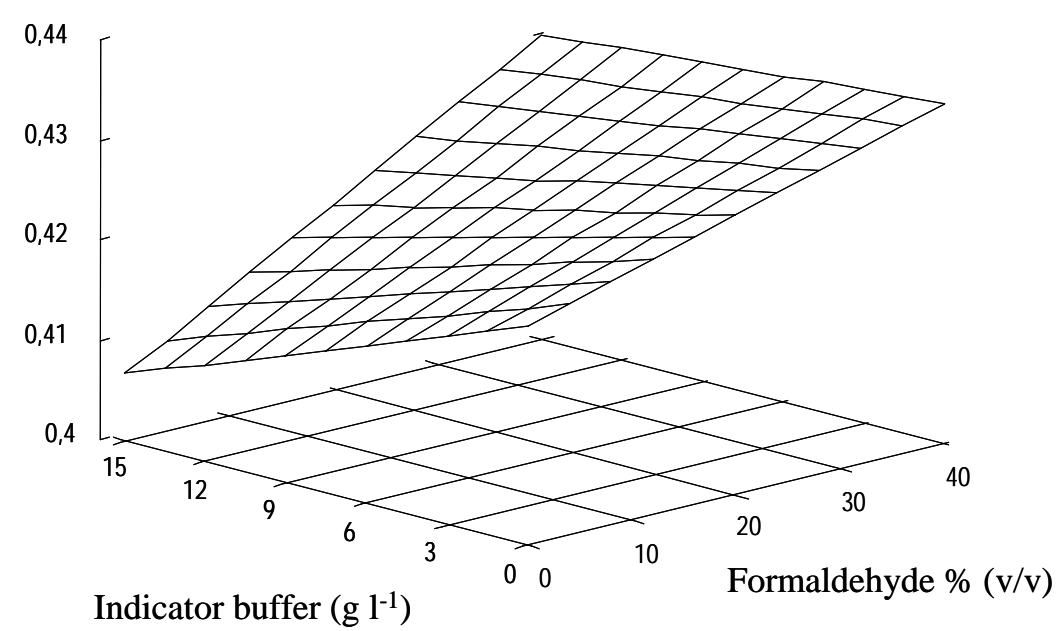

Figure 2. Response surface of the multivariate analysis: evolution of absorbance versus buffer concentration $\left(\mathrm{g} \mathrm{l}^{-1}\right.$ ) in the indicator solution and formaldehyde concentration (\% $(\mathrm{v} / \mathrm{v}))$.

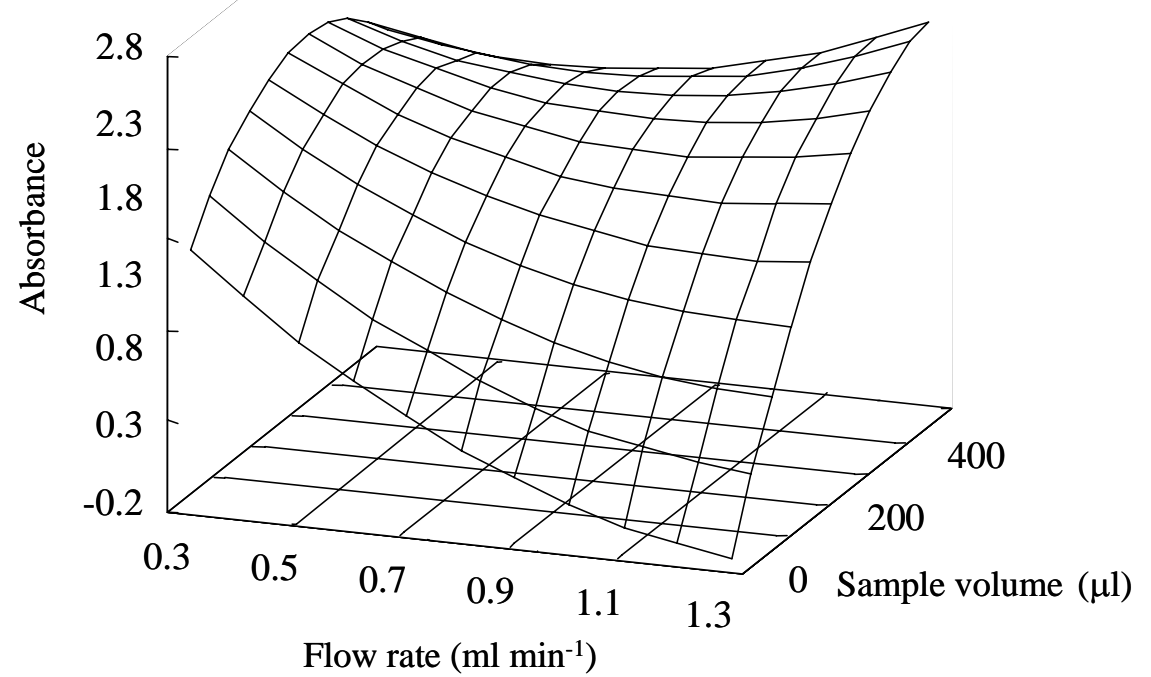

Figure 3. Response surface of the multivariate analysis: evolution of absorbance versus flow-rate $\left(\mathrm{ml} \mathrm{min}^{-1}\right)$ and sample volume $(\mu \mathrm{l})$. 
Linear responses were found in the range of concentrations studied. In the case of must, a loss of linearity was observed for concentrations higher than $400 \mathrm{mg} \mathrm{l}^{-1}$. A logarithmic response was found for these concentrations. The concentrations of the target parameter (r.a.n.) were in the range $15-60 \mathrm{mg} \mathrm{l}^{-1}$ and 15-400 $\mathrm{mg} \mathrm{l}^{-1}$, for wines and must, respectively. The presence of $\mathrm{SO}_{2}$ from $1 \mathrm{mg} \mathrm{l}^{-1}$ to $50 \mathrm{mg} \mathrm{l}^{-1}$ did not interfere in the analysis, nor did carbon dioxide. Then, samples of both wines and must were analysed.

\section{Assessment of the proposed method}

Thirty different white wines and ten must samples were used in the assessment study. Each value was the average of three determinations. The protocol for assessment consisted of studying the analytical parameters, such as linear range, traceability with a reference method, repeatability, reproducibility, detection and quantification limits and sample throughput. A robustness study was also developed.

\section{Repeatability ( $r$ )}

The $\mathrm{F}$ test was applied in order to establish whether the differences between the repeatabilities of the methods were significant. With this aim, Fobs $=\mathrm{S}_{\mathrm{r}}^{2} / \mathrm{S}_{\mathrm{ref}}{ }^{2}$ was compared with the $F_{1-\alpha}$ obtained from $F$ tables for $\alpha=0.05$ ( $P=95 \%)$. As can be observed in Table 2, Fobs $<\mathrm{F}_{1-\alpha}$, and so the repeatabilities of the FI and reference methods are similar. It is worth pointing out that the repeatability of the FI method is better than that of the reference method.

\section{Reproducibility ( $R$ ) (30 days)}

Table 2 also shows the $R$ values obtained, as well as the results from the application of the $\mathrm{F}$ test. The reproducibility of the FI method is better than that of the reference method. Both methods are statistically equal.

Table 2. Analytical characteristics of the proposed method as compared with the reference method

\begin{tabular}{lll}
\hline Parameter $^{\mathrm{a}}$ & Reference & \multicolumn{1}{c}{ Flow injection } \\
\hline${\text { Repeatability/ } \mathrm{mg} \mathrm{l}^{-1}}_{\mathrm{S}_{\mathrm{I}} / \mathrm{mg} \mathrm{l}^{-1}}$ & 4.10 & 1.35 \\
${\text { Reproducibility/ } \mathrm{mg} \mathrm{l}^{-1}}_{\mathrm{S}_{\mathrm{R}} / \mathrm{mg} \mathrm{l}^{-1}}$ & 0.67 & 0.4725 \\
$\mathrm{Fobs}^{\mathrm{r}}$ & 6.30 & 3.94 \\
$\mathrm{Fobs}^{\mathrm{R}}$ & 1.98 & 1.23 \\
$\mathrm{~F}_{1-\alpha}(\mathrm{n}=30)$ & - & 0.497 \\
$\mathrm{LOD} / \mathrm{mg} \mathrm{l}^{-1}$ & - & 0.386 \\
$\mathrm{LQ} / \mathrm{mg} \mathrm{l}^{-1}$ & - & 1.69 \\
$\mathrm{Sample}$ throughput/ & -1 & 10 \\
\hline${ }^{\mathrm{a}} \mathrm{Sr}$ and SR are the deviations of repeatability and reproducibility, respectively. Fobs $=\mathrm{S}_{\mathrm{r}}{ }^{2} / \mathrm{S}_{\text {ref }}{ }^{2}$
\end{tabular}




\section{Detection (LOD) and quantification (LQ) limits}

Table 2 shows that the best LOD and LQ correspond to the reference method, but those provided by the FI method are not far from the reference values as only an approximate value is required.

\section{Traceability}

The traceability of the methods was studied by comparing the results obtained from 30 samples of different white wines and 10 must samples analysed by both the reference and proposed method. Fig. 4 shows the regression of the FI method for r.a.n. on the reference method. The regression equation, $\mathrm{Y}=0.9999 \mathrm{X}-1.34 \quad \mathrm{r}=$ 0.990 ), shows good correlation between the data from both methods. Confidence limits of $95 \%$ are shown in Fig. 4 in dotted lines. In both cases, the traceability was assured using the t-test. The data used in the correlation study of the methods were subjected to previous processing because of the presence of a systematic and a constant error in all concentration ranges studied. In this way, the systematic error was perfectly known, evaluated and substracted from the raw data, as the error increased the analytical signal by a value of 2.144. This systematic error was due to the contribution of the following effects: (i) a significant matrix effect due to organic acids present in wine; and (ii) changes in the standard method when adapted to the dynamic approach (no barium chloride was used). This last aspect was checked in both batch and dynamic methods by either adding or not, barium chloride to 10 wine samples in order to precipitate proteins.

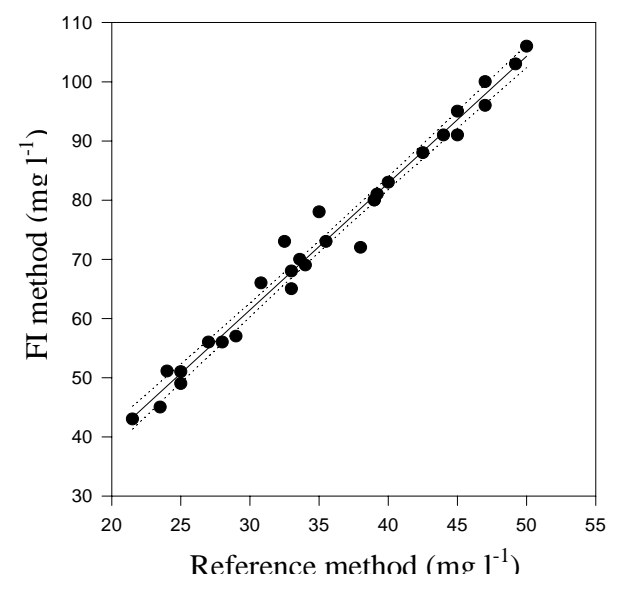

Figure 4. Correlation graph of the reference method with the FI method for the determination of readily assimilable nitrogen. Interval of confidence, 95\%.

The results provided by the batch method showed a constant difference between the results obtained in the presence and absence of barium chloride in all instances. The same experiment performed in the FI manifold by either adding, or not, barium chloride to the samples $15 \mathrm{~min}$ before injection showed no differences between treated and non-treated samples. FI yields an error lower than $10 \%$, which is acceptable for winery uses.

\section{Sample throughput}

The results in Table 2 show that the FI method has a sampling frequency much 
higher than that of the reference method (20 vs 2 h. $^{-1}$ ).

\section{Robustness study}

The study was developed using the Younden-Steiner ${ }^{11}$ procedure. Critical variables of the system are the flow rate and the concentrations of formaldehyde, bromothymol blue and buffer in both the indicator and formaldehyde solutions. These variables were modified $\pm 10 \%$ from their optimum values. Errors lower than 5\% were observed, except for the indicator solution, which yielded changes of $8 \%$ of the analytical signal in the range under study.

\section{Application of the method}

A study of the r.a.n. content in 120 samples was made by the proposed method. The collection of 120 samples was the result of programmed sampling of barrels and tanks following the traditional "criaderas" and "soleras" system. Aging of Sherry wine is a dynamic, not static, process, involving periodic partial transfers from barrels of a young wine to those with an old wine. Thus, from each barrel containing the wine in the oldest aging state (named as "solera"), a fraction is withdrawn for fining and bottling. The "solera" barrels are filled with the same volume of wine from a barrel row at an earlier aging state (the first "criadera”), which in turn receives wine from other barrels of younger wine (second "criadera"), and so on. The row at lowest aging state (third "criadera") is filled every 5-6 months with not aged wine from the tanks. The minimum duration of the aging process of Sherry wine is $2.0-2.5$ years.

Due to the high number of barrels in the winery (almost 10000) and tanks (almost 280) the application of the reference method for the analysis of the 120 samples would require 9 days. Using the developed FI method the analysis was performed in one day.

The result of the analyses of samples from "criaderas" and "soleras" yielded not difference in r.a.n. contents, which were between 25 and $35 \mathrm{mg} \mathrm{l}^{-1}$. When the tanks were studied, differences were found depending on the presence or absence of "flor yeast". The highest values of r.a.n. in tanks ranged between 50 and $60 \mathrm{mg} \mathrm{l}^{-1}$.

\section{Conclusions}

The proposed method shows sufficient precision for the needs of wineries and can be used to test nitrogen availability (r.a.n.) for both fermentation and biological aging processes. It is a simple, inexpensive method, which presents a good correlation with the reference method used commonly for the determination of this parameter and could be easily implemented in wineries. Other advantages of the method reported here are the capability for easy automation and a sampling throughput higher than that of the method used routinely in wineries. This latter aspect allows to analyse a large number of barrels, thus providing valuable biological information on the nutritional state of the "flor yeast" . 


\section{Acknowledgement}

The Spanish Comisión Interministerial de Ciencia y Tecnología (CICyT) is thanked for financial support (Project BQU 2000/ 0241).

\section{References}

(1) P.Ribereau-Gayon, Y. Glories, A. Maujean, D. Dubordieu, Handbook of enology. Volume 2. The Chemistry of wine. Stabilization and treatments, John Wiley \& Sons Ltd., Chichester, 2000, p. 100.

(2) C. Flanzy, Enología: Fundamentos científicos y tecnológicos, AMV Ed. Mundi Prensa, Madrid, 2000, p. 222.

(3) E.A. Crowell, C.S. Ough, A. Bakalisnky, Am. J. Enol. Vitic., 1985, 36, 175.

(4) H. Rosen, Arch. Biochem. Biophys., 1957, 67, 10.

(5) Recueil des méthodes Internationales d'Analyse des Vins et des Mouts, Office International de la vigne et du vin (OIV), Paris, 1990.

(6) P. Giannessi, M. Matta, Trattato di Scienzia e Tecnica Enologica, Vol I, Analisi e controllo dei mosti $e$ dei vini, AEB Brescia Ed., Brescia, 1987, p 87.

(7) D. Delmas, M.G. Frikha, E.A.S. Linley, Mar. Chem., 1990, 29, 145.

(8) I.R.C. Whiteside, P.J. Worsfold, E.H. McKerrell, Anal. Chim. Acta, 1988, 15, 343.
(9) I.R.C. Whiteside, P.J. Worsfold, A. Lynes, Anal. Chim. Acta, 1987, 192, 77.

(10) S.Z. Yao, X.L. Su, J. AOAC Int., 1999, 82, 1479.

(11) J. Younden and E.H. Steiner, Statistical Manual of the Association of Oficial Analytical Chemist (AOAC), AOAC, Washington DC, 1975. 